\title{
DLC1 suppresses NF-KB activity in prostate cancer cells due to its stabilizing effect on adherens junctions
}

\author{
Veenu Tripathi, Nicholas C Popescu* and Drazen B Zimonjic
}

\begin{abstract}
DLC1 (Deleted in Liver Cancer 1) gene encodes a RhoGTPase-activating protein (RhoGAP), which exerts most of its tumor suppressor functions through suppression of small Rho GTPases proteins RhoA, RhoB, RhoC and to some degree Cdc42, but not Rac. RhoGTPases are implicated in NF-kB activation in highly invasive prostate carcinoma (PCA), with consequences on cell proliferation, survival and metastatic capacity. Here we demonstrate that DLC1 transduction in two androgen-independent (AI) and highly metastatic PCA cell lines negatively regulates NF-KB activity in a GAP- and a-catenin-dependent manner. Expressed DLC1 protein suppresses the phosphorylation of NF-KB inhibitor, $\mathrm{IKBa}$, causes its relocation from membrane ruffles into cytoplasm and attenuates its ubiquitination and subsequent degradation. DLC1-mediated NF-kB suppression and its effects are comparable to NF-KB inhibition using either shRNA knockdown or peptide inhibitor. Expression of transduced DLC1 suppressed the expression of NF-kB mediated genes. Such effects were found to be reliant on presence of calcium, indicating that the observed modifications are dependent on, and enabled by DLC-mediated stabilization of adherens junctions. These results expand the multitude of DLC1 interactions with other genes that modulate its oncosuppressive function, and may have potential therapeutic implications.
\end{abstract}

Keywords: DLC1; NF-kB; Rho; Adherens junction (AJ); Prostate cancer

\section{Background}

Metastatic prostate cancer (PC), resistant to conventional therapies, hormone deprivation and ablation, is one of the leading causes of death of men in United States. In about one third of post-prostatectomy patients, tumor cells reappear as local or distant metastasis, develop hormone refractoriness and acquire increasingly more aggressive phenotype. A growing body of evidences shows that a transcriptional factor NF- $\mathrm{kB}$ is constitutively activated in primary PC (Suh et al. 2002), and plays an important role in tumor invasion, metastasis, angiogenesis, and acquisition of chemotherapy resistance (Sweeney et al. 2004; Catz and Johnson 2001).

Although commonly called NF-kB, it is in fact a group of related homo- and heterodimeric transcription factors composed of five members of the Rel/NF- $\mathrm{kB}$ family

\footnotetext{
* Correspondence: popescun@mail.nih.gov

Laboratory of Experimental Carcinogenesis, National Cancer Institute, National Institutes of Health, 37 Convent Drive, MSC 4262, Bethesda, Maryland 20892, USA
}

of proteins - RelA (p65), RelB, c-Rel, NF-kB1 \{p50) and NF-kB2 (p52) - all of which contain a conserved Rel homology region and $\mathrm{C}$ - and $\mathrm{N}$-terminal domains responsible for dimerization and DNA binding, respectively (Hoffmann et al. 2003). Activation of NF- $k B$ occurs when its specific inhibitor from the Ik-B family of proteins gets phosphorylated (and subsequently degraded) by either tripartite (IKK $\alpha, I K K \beta, I K K \gamma)$ or homodimeric (IKK $\alpha$, IKK $\alpha$ ) I-kB kinase (IKK) complex (Ghosh and Karin 2002; Luo et al. 2005). Upon activation NF- $\mathrm{kB}$ relocates from cytoplasm to nucleus where, after some additional molecular modifications, it binds to promoter region of numerous genes involved in inflammatory response, cell growth, apoptosis and differentiation. Increased action of IKK complex appears to be in the root of constitutive NFKB activity in PC (Palayoor et al. 1999; Pajonk et al. 1999), which affects expression of genes like cyclin D1, c-myc and Bcl-2 that drive cellular proliferation or confer resistance to apoptotic signals. NF-kB-mediated expression of genes like

\section{黑 Springer}


IL-8, VEGF, MMP9, vimentin, uPA and UPA receptor, further contribute to the development of aggressive PCA (Karin et al. 2002).

On the other side, among multiple factors implicated in the initiation and progression of PC (Xu et al. 2002; Albany et al. 2011; Hsieh et al. 2001) tumor suppressor gene DLC1, a member of RhoGAP family of genes, stands out, as it has been shown to be down-regulated or absent not only in PC, but in various other solid tumors and hematological malignancies (Guan et al. 2006; Durkin et al. 2007; Ullmannova et al. 2009). Introduction of DLC1 in highly metastatic PCA cells suppressed proliferation, invasiveness and anchorage-independent growth and restored response to apoptotic signaling (Guan et al. 2008). Conversely, DLC1 silencing in prostate epithelial cells promoted pro-angiogenic responses through upregulation of vascular endothelial growth factor (VEGF), accompanied by the accumulation of hypoxia-inducible factor $1 \alpha$ and its nuclear localization (Shih et al. 2010).

The rationale for undertaking this study was based on evidence showing that NF- $\mathrm{kB}$ is constitutively activated in PC cells, is a major transcription factor involved in metastasis to bone, and, importantly, DLC1expression suppresses proliferation of PC cells in vitro, and their growth in nude mice (Andela et al. 2003, Guan et al. 2008). We used metastatic, androgen-independent PCA cell lines C4-2-B2 and PC-3, deficient in DLC1 expression but with high $\mathrm{NF}-\mathrm{kB}$ activity, to examine the relationship between NF-kB and DLC1 and showed that in these cells restoration of DLC1 expression inhibited the phosphorylation (i.e. activation) of NF- $\mathrm{kB}$ in the $\alpha$-catenin- and GAPdependent manner.

\section{Results}

DLC1 suppresses NF-KB activity in prostate cancer cells When compared to normal, immortalized, DLC1positive prostate epithelial cell RWPE-1, metastatic PCA cells C4-2-B2 and PC-3 showed (Figure 1A, B) lack of DLC1 expression, higher levels of active Rho, and significantly higher levels of NF- $\mathrm{kB}$ activation, as measured by phosphorylation of p65 subunit of NF- $\mathrm{kB}$. Transduction of DLC1 into C4-2-B2 cells, and restoration of its expression to the level comparable to that in RWPE-1 (Figure 1B), reduced activation of NF- $\mathrm{kB}$ as demonstrated by both p 65 phosphorylation (Figure $1 C$ ) and by luciferase reporter assay (Figure $1 \mathrm{D})$. On the other hand, reexpression of DLC1 in PC3 cells did not significantly affect NF- $\mathrm{kB}$ activation (Figure $1 \mathrm{C}, \mathrm{D}$ ), although a DLC1 was suppressing active RhoA in both cells (Figure 1C). Knocking down of both DLC1 and $\alpha$-catenin in RWPE- 1 cells suppresses the phosphorylation of p65 subunit of NF- $\mathrm{kB}$ and, thus, underscores the role of DLC1 and $\alpha-$ catenin in NF- $\mathrm{kB}$ activity (Figure 1E).

\section{DLC1-mediated suppression of NF-KB is $\alpha$ - catenin dependent}

Since PC3 cells, in addition to absence of DLC1 expression, also lack expression of $\alpha$ - catenin, which is abundantly expressed in C4-2-B2 cells, we hypothesized that $\alpha$-catenin might be a "missing link" in DLC1-mediated inhibition of NF- $\kappa \mathrm{B}$ activation of PC3 cells. We, therefore, probed extracts of C4-2-B2 and PC-3 cells with antiphospho-p65 antibody, to see if $\alpha$-catenin status affects p65 phosphorylation and activation of NF-kB. In both cell lines simultaneous expression of DLC1 and $\alpha$-catenin was associated with lower levels of p65 phosphorylation, indicative of reduced NF-kB activation (Figure 2A). Confocal imunnofluorescence analysis of C4-2-B2 and PC-3 cells (Figure 2B) also showed that presence of either DLC1 or $\alpha$-catenin did not affect the nuclear phosphorylated $N F \kappa B$, but that co-expression of DLC1 and $\alpha$-catenin reduced the amount of active NFKB below the level of detection. NF- $\kappa B$ luciferase reporter gene assay (Figure $2 \mathrm{C}$ ) provided additional confirmation that both DLC1 and $\alpha$-catenin are required for the maximum suppression of $N F \kappa B$ activation; used alone neither the full-length DLC1 nor $\alpha$-catenin were not able to produce a statistically significant effect.

\section{RhoGAP activity and interaction with $a$-catenin is required for NF-KB down regulation}

To see if DLC1-mediated inhibition of NF- $\mathrm{KB}$ activity was RhoGAP-dependent, C4-2-B2 cells were either transduced with wild-type DLC1, or transfected with DLC1 GAP mutant R718E. In the later case, stable clones were selected using G148. Subsequent comparison of NF-kB p65 subunit phosphorylation in aforementioned GAP-competent and GAP-incompetent C4-2-B2 cells showed no reduction in 655 phosphorylation and, therefore, no inhibition of NF- $\mathrm{BB}$ activation in cells bearing mutant GAP (Figure 3A). In addition, cells transfected with DLC1 deletion mutant $\triangle 340-435$, lacking the critical $\alpha$-catenin-binding region, also were not able to suppress the phosphorylation and activation of $\mathrm{NF}-\mathrm{\kappa B}$ (Figure 3A). Luciferase reporter gene activation assay confirmed these observations (Figure 3B), which, together, revealed that DLC1-mediated NF- $\mathrm{KB}$ regulation depends on both the DLC1 RhoGAP activity, and on its ability to effectively bind $\alpha$-catenin.

\section{DLC1-mediated adherens junctions stabilization is responsible for inhibition of NF-KB activity}

The integrity of adherens junctions (AJ) is affected by availability of calcium ions $\left(\mathrm{Ca}^{2+}\right)$; depletion of $\mathrm{Ca}^{2+}$ disrupts AJs as shown by E-cadherin staining of DLC1-transduced C4-2-B2 cells, and cells with DLC1 deletion mutant $\Delta 340-435$, lacking the critical $\alpha$-catenin-binding region (Figure 4A). Interestingly, such cells with compromised AJ 

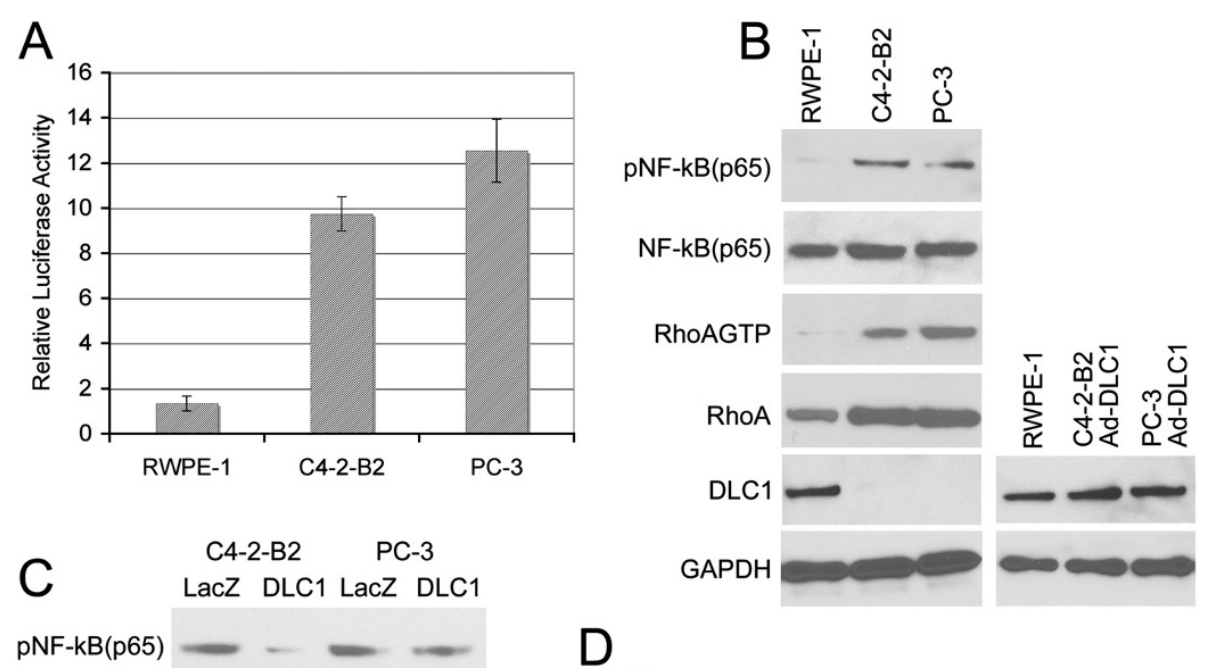

$\mathrm{D}$
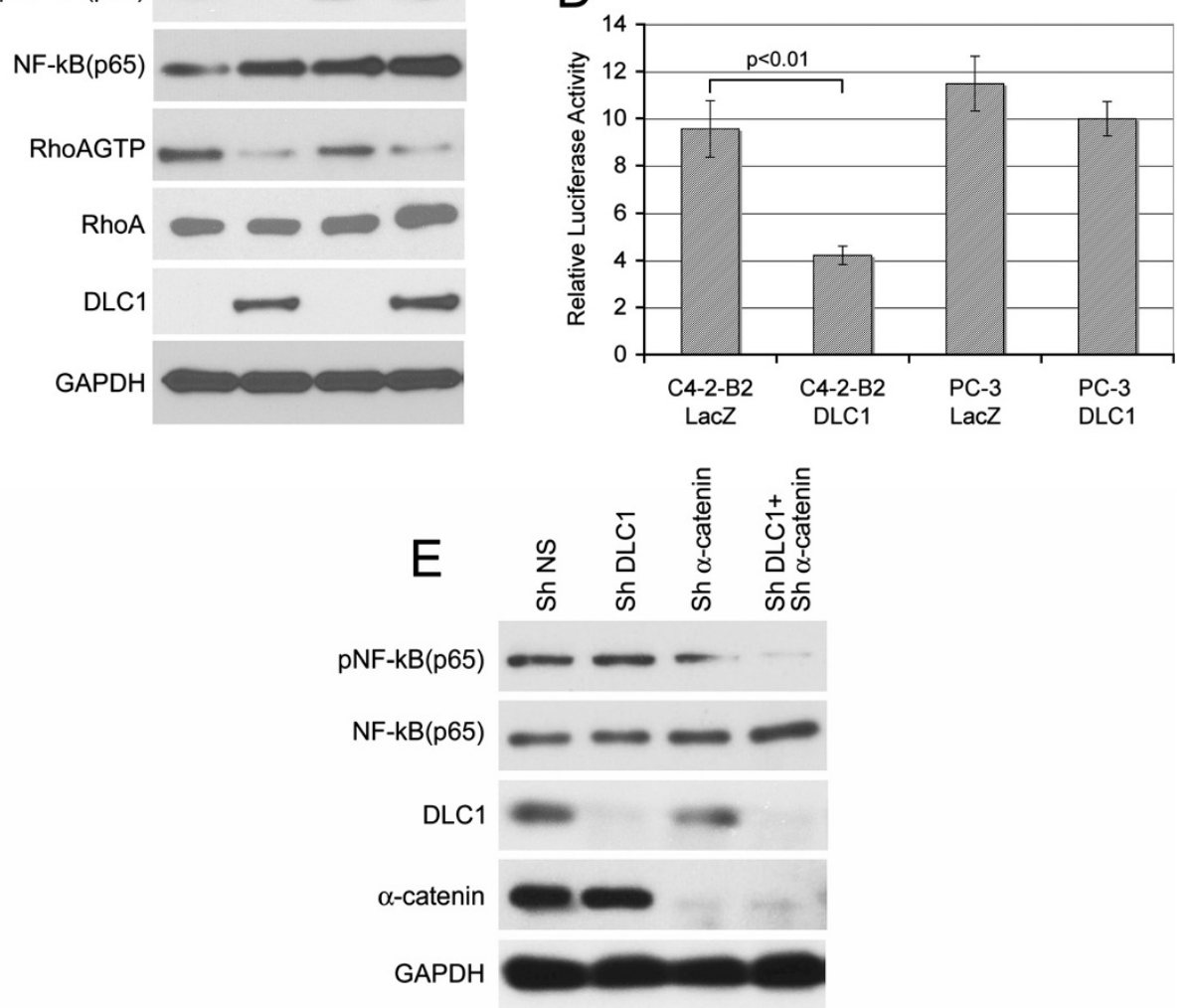

Figure 1 DLC1 suppresses NF-KB activation. (A) Relative luciferase activity of NF-KB reporter in RWPE-1, C4-2-B2 and PC-3 cells, (B) Western blot showing the level of DLC1, pNF-KB (p65), NF-KB (p65), RhoAGTP, and total RhoA in RWPE-1, C4-2-B2 and PC-3 cells and level of DLC1 in RWPE-1 and Ad-DLC1 transduced (50MOI) C4-2-B2 and PC-3cells. (C) Western blot showing level of phosphorylated p65 subunit of NF-KB in the Ad-Lac Z and Ad-DLC1 transduced C4-2-B2 and PC-3 cells. (D) Relative luciferase activity of NF-KB reporter in AD-LacZ and DLC1 transduced C4-2-B2 and PC-3 cells. All values are means \pm SD of three independent counts. (E) Western blot showing the level of phosphorylated p65 subunit of NF-KB in DLC1- and a-catenin-knock down RWPE-1 cells.

integrity show activation of NF- $\mathrm{BB}$, as demonstrated by anti-pNF- $\mathrm{kB}$ staining in absence of $\mathrm{Ca}^{2+)}$ (Figure 4B) and confirmed by luciferase reporter assay (Figure $4 \mathrm{C}$ ). To examine if DLC1-mediated stabilization of AJs would reduce NF- $\mathrm{kB}$ activity by enabling its binding to AJ's proteins, primarily E-cadherin, C4-2-B2 cells transduced with either LacZ or DLC1, were additionally transfected with GFP E-cadherin (Figure 4D right), their respective cell extracts immunoprecipitated with anti-GFP, and those immunoprecipitates probed with anti-NF- $\mathrm{KB}$ antibodies. When compared to DLC1-negative LacZ-transduced cells, DLC1-positive cells exhibited increased amounts of 


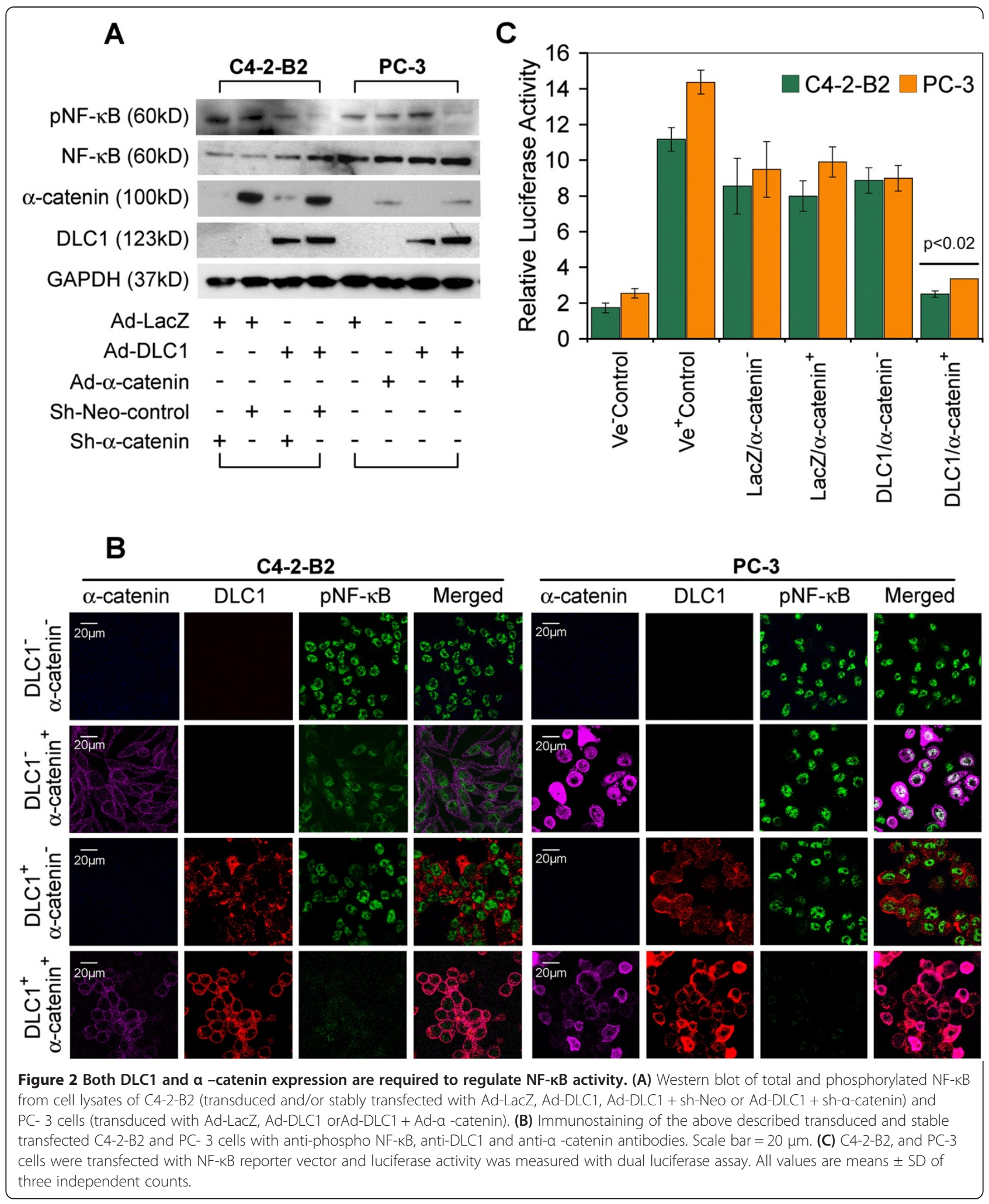

NF- $\kappa B$ associated with E-cadherin (Figure 4D left) and reduced NF- $k B$ activity. Furthermore, analysis of membrane and cytosolic fractions of LacZ- or DLC1-transduced C4-2-
B2 cells, showed a pronounced shift in NF- $\mathrm{kB}$ distribution from cytosole to membrane in DLC-positive cells (Figure 4E), indicating that DLC1-mediated stabilization 

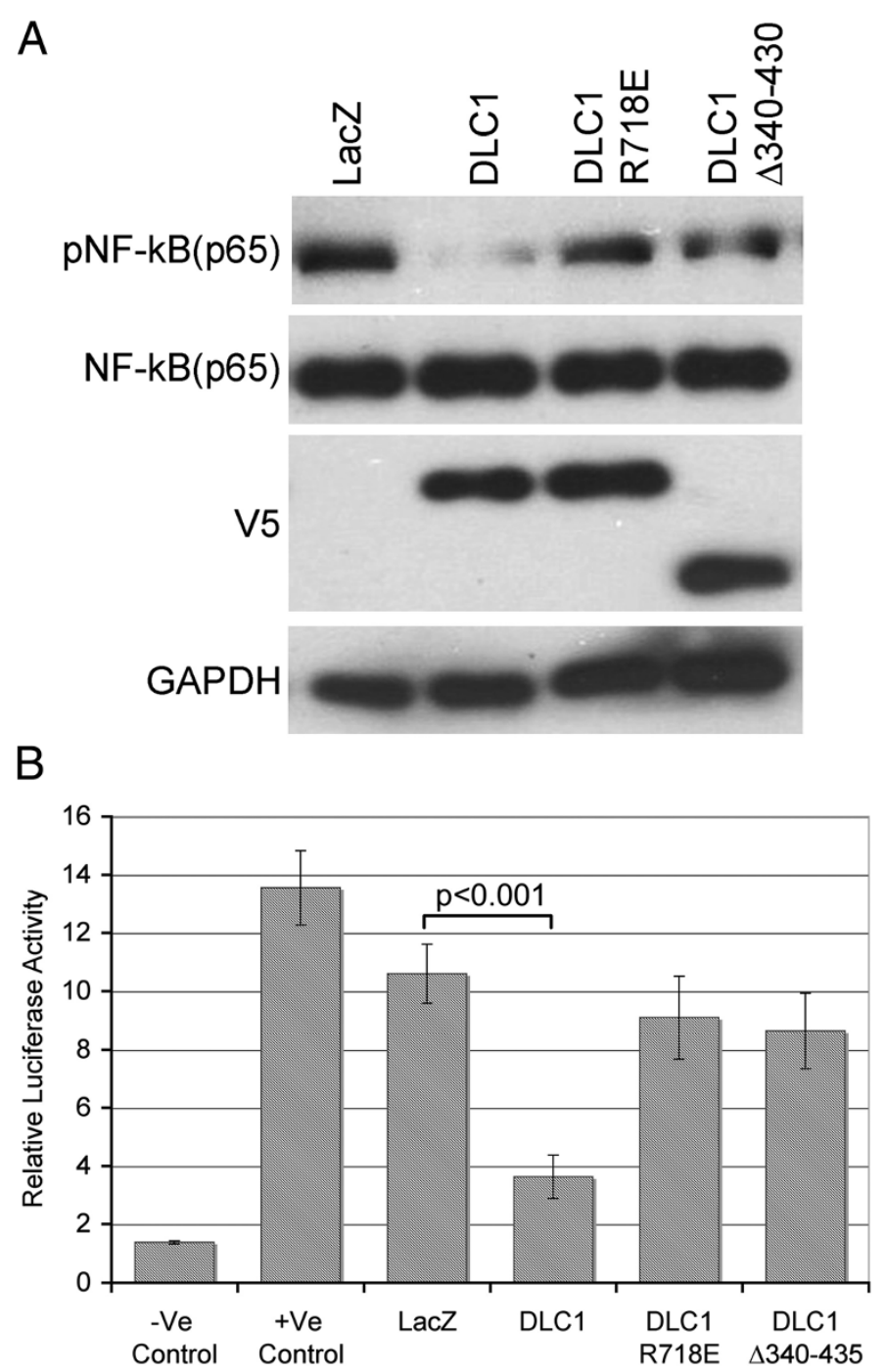

Figure 3 Suppression of NF-KB activity is GAP- and a -catenin-dependent (A) Western blot of pNF-KB (p65), NF-KB (p65) and DLC1 (V-5) expression in C4-2-B2 cells transduced with Ad-Lac Z or Ad-DLC1 and stably transfected with either DLC1 GAP-mutated (R718E) or a -catenin binding deficient constructs $(\mathbf{\Delta} \mathbf{3 4 0}-\mathbf{4 3 5})$. (B) Dual Luciferase reporter assay for NF-KB activity in above-mentioned C4-2-B2 cells. All values are means \pm SD of three independent counts.

of AJs plays an important role in modulating NF- $\mathrm{KB}$ activity.

\section{DLC1 inhibits IKBa localization to membrane ruffles and proteasomal degradation}

To further explore the mechanism through which DLC1 modulates NF- $\mathrm{kB}$ activity, we examined phosphorylation of NF-kB's specific inhibitor, IкB $\alpha$, a molecular modification instrumental for the release of active NF- $\mathrm{kB}$ to nucleus. As shown in Figure 5A, phosphorylation of ІкB $\alpha$ was decreased in the presence of DLC1. Use of DLC1 deletion mutant $\Delta 340-435$ caused no effect on pIkB phosphorylation, thus affirming the role of this region of DLC1 in the signaling.
Confocal microscopy analysis of ІкB $\alpha$ cellular distribution showed that in DLC1-negative C4-2-B2 cells the inhibitor was localized to the membrane ruffles. Transduction and expression of DLC1 was followed by IKB $\alpha$ distribution throughout the cytoplasm but, interestingly, $\mathrm{Ca}^{2+}$ depletion reversed that process causing $I \kappa B \alpha$ to withdraw to membrane again (Figure 5B). Expression of DLC1 deletion mutant $\Delta \mathrm{D} 340-435$ lacking the $\alpha$-catenin-binding region, was not able to completely relocalize IкB $\alpha$ to the cytoplasm, and certain amount of I $\mathrm{K} \mathrm{B} \alpha$ remained present in the membrane ruffles (Figure 5B).

Ubiquitination assay of IкB $\alpha$ showed that the expression of wild-type DLC1 attenuated ubiquitination of ІкB $\alpha$, whereas GAP-incompetent DLC1 mutant R718E failed to produce such an effect (Figure $5 \mathrm{C}$ ). Here again elimination 


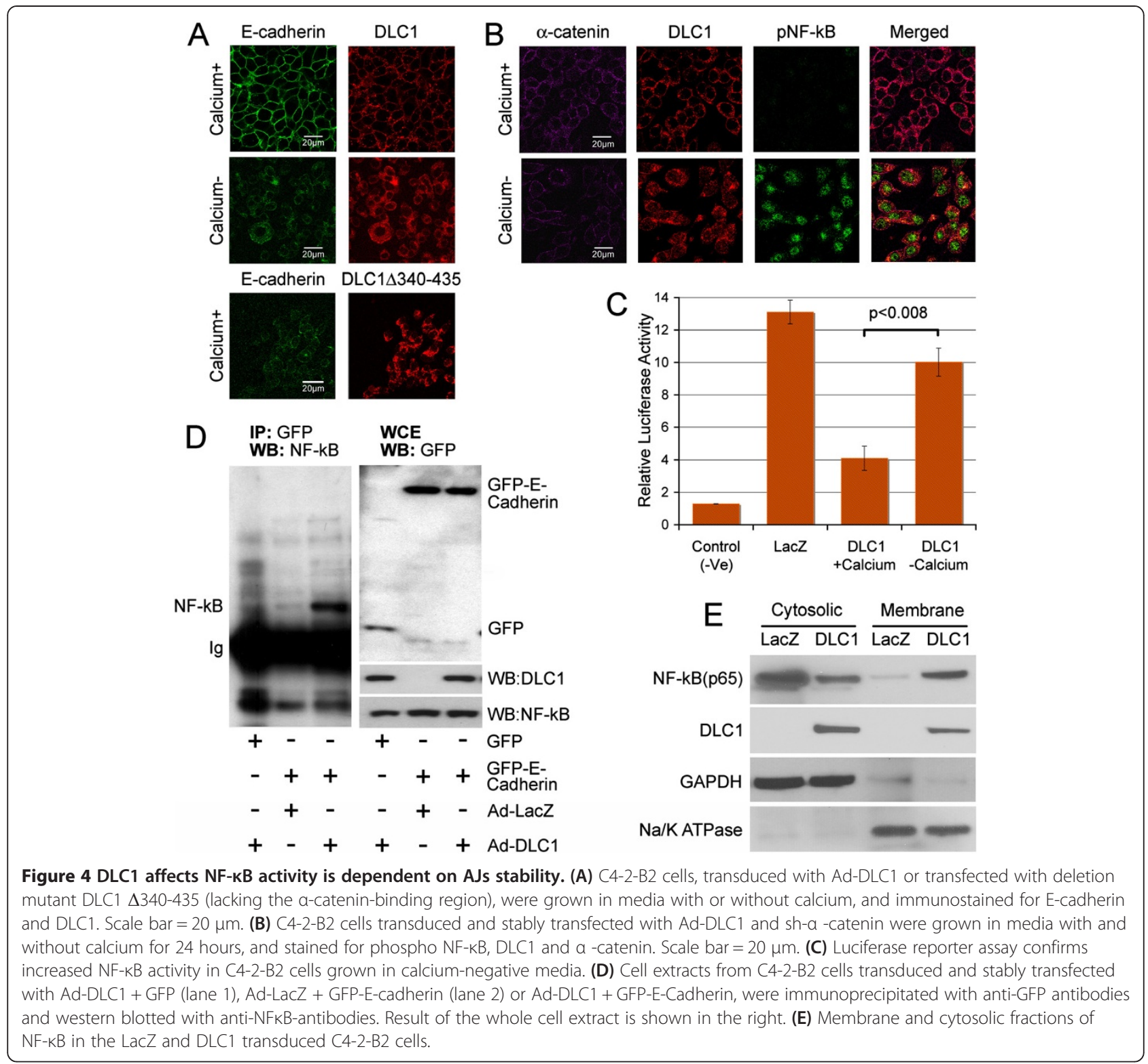

of calcium from culturing media reversed the effects of DLC1 expression, i.e., increased the ubiquitination of IкB $\alpha$, suggesting that DLC1-mediated stabilization of AJs,

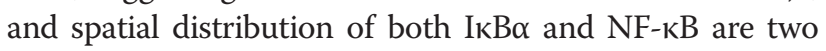
major factors affecting NF- $\mathrm{kB}$ signaling.

Colony formation, invasiveness and apoptosis of metastatic prostate carcinoma cells are affected similarly by DLC1-mediated NF-KB suppression, sh(p65)NF-KB silencing or pharmacological down-regulation of NF-KB

To better understand the magnitude and the consequences of DLC1-mediated suppression of NF- $\mathrm{kB}$ activation, DLC1negative C4-2-B2 cells were either transduced by DLC1 gene, or treated by shRNA (targeting p65 subunit of NF$\kappa B)$, or by pharmacological NF- $\kappa B$ peptide inhibitor. Use of $\operatorname{sh}(\mathrm{p} 65) \mathrm{NF}-\mathrm{kB}$ significantly reduced NF- $\mathrm{kB}$ expression on protein level (Figure 6A) whereas use of $150 \mu \mathrm{M}$ peptide inhibitor completely abolished NF- $\mathrm{\kappa B}$ transcriptional activity. Expression of DLC1 protein reduced colony formation efficiency, and invasion capability of C4-2-B2 cells, to the levels similar to one caused by $\operatorname{sh}(\mathrm{p} 65) \mathrm{NF}-\mathrm{kB}$ or by chemical NF- $k B$ peptide inhibitor (Figure $6 \mathrm{~B}, \mathrm{C}$ ). The same pattern was observed in apoptosis assay where DLC1 effect was comparable to the ones caused by NF-kB inhibitors (Figure 6D). In addition, expression of several $\mathrm{NF}-\mathrm{kB}$-inducible genes with roles in cell proliferation, invasion and apoptosis - such as cyclin D1, c-Myc, Bcl-xL and vimentin - was notably suppressed by simultaneous co-expression of DLC1 and $\alpha$-catenin, in a pattern similar to the effect of NF-kB peptide inhibitor (Figure 6E), which, 


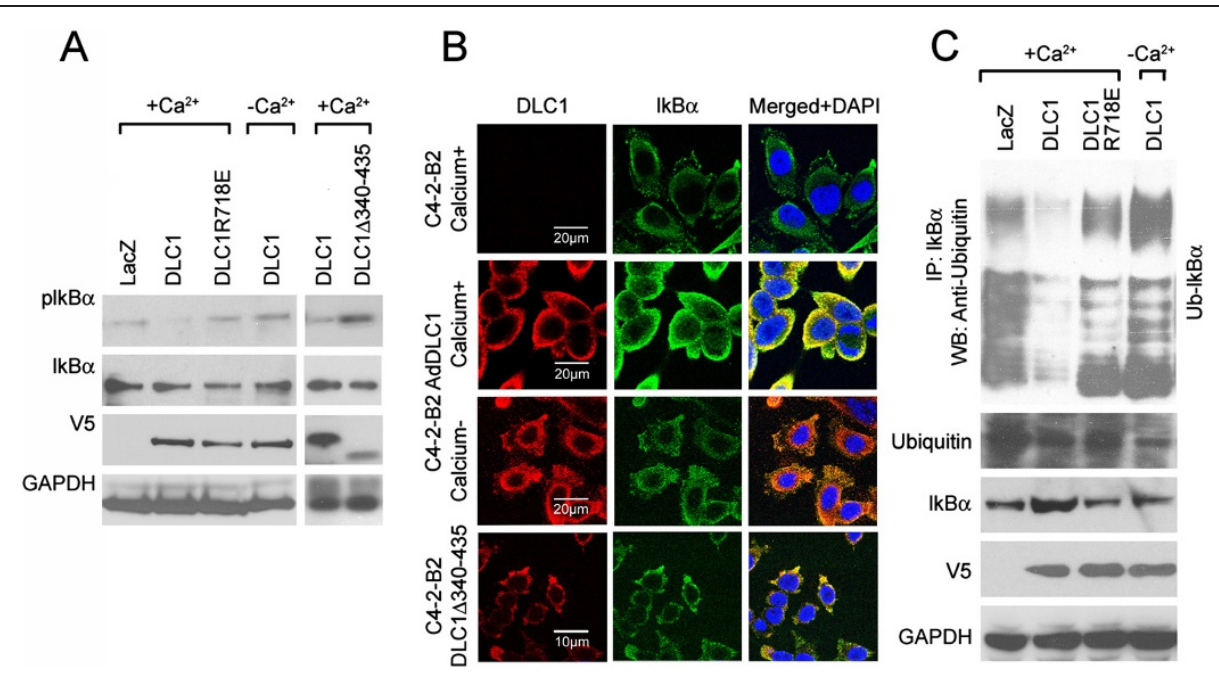

Figure 5 DLC1 expression causes relocation and suppresses phosphorylation and ubiquitination of IKBa. (A) Western blots of phospho-IKBa and total IkBa in Ad-LacZ-, Ad-DLC1-transduced or DLC1 deletion mutant $\triangle \mathrm{D} 340-435$-transfected C4-2-B2 cells. (B) IkBa localization in Ad-LacZ-, Ad-DLC1-transduced or DLC1 deletion mutant $\triangle \mathrm{D} 340-435$-transfected C4-2-B2 cells in the presence and absence of calcium. Scale bars $20 \mu \mathrm{m}$ and $10 \mu \mathrm{m}$, respectively. (C) Ubiquitination assay of IKBa of proteasome inhibitor MG132 treated Ad-LacZ and Ad-DLC1 transduced C4-2-B2 and DLC1R718E transduced cells in the presence and absence of calcium.

altogether, further underscores the significance of DLC1 in NF-kB- mediated signaling.

\section{Discussion}

This study demonstrates that DLC1 expression in androgenindependent and highly metastatic PCA cells C4-2-B2 and $\mathrm{PC}-3$ with constitutive activation of NF-KB (Gasparian et al. 2002) negatively regulates NF- $\mathrm{KB}$ activity in a GAPand $\alpha$-catenin-dependent manner. DLC1 suppresses the

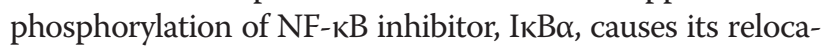
tion from membrane ruffles, and attenuates its ubiquitination and subsequent degradation. DLC1-mediated NF-kB suppression and its consequences were comparable to NF$\kappa \mathrm{B}$ inhibition using either shRNA knock down or NF- $\mathrm{kB}$ peptide inhibitor. In addition, DLC1 transduction suppressed the expression of NF- $\mathrm{kB}$ mediated genes. These effects were found to be reliant on presence of calcium, which indicates that the observed modifications are dependent on, and enabled by DLC1-mediated stabilization of adherens junctions (Tripathi et al. 2012).

Constitutive activation of NF-kB pathway in prostate, lung, liver and breast cancers (Gasparian et al. 2002; Chiao et al. 2002; Biswas et al. 2004), correlates with the expression of several genes involved in immune and inflammatory responses, neoangiogenesis, increased cell proliferation, epithelial-to-mesenchymal transition (EMT) and in acquired resistance to apoptosis (Huber et al. 2004; Pikarsky et al. 2004; Julien et al. 2007; Pickering et al. 2007; Hafeez et al. 2008). NF-кB has been shown to promote breast cancer metastasis (Park et al. 2007), and appears to be a major regulator of prostate cancer cells metastasis to bone (Andela et al. 2003). Inhibition of NF$\mathrm{KB}$ activity in tumor cell lines increases their sensitivity to chemotherapeutic drugs and radiation (Amit et al. 2003; Tapia et al. 2007). Transcriptional activation of NF- $k B$ is effectively induced - independent of RasGTPase and Raf-1 kinase - by members of Rho family of small GTPases, that include RhoA, Cdc42 and Rac1 (Hodge et al. 2003; Perona et al. 1997; Cammarano and Minden. 2001; Gnad et al. 2001). Conversely, blockage of Rho pathways leads to suppression of NF- $\kappa B$ activity (Segain et al. 2003). This relationship is becoming increasingly important in deciphering regulatory underpinning of one of the crucial elements of metabolic reprogramming of cancer cell - it's greatly elevated glutamine metabolism - where, apparently, activation of the predominant isoform of mitochondrial enzyme glutaminase is substantially influenced by concomitant RhoGTPase signaling and NF-kB activation (Wilson et al. 2013).

Main function of DLC1 gene-encoded protein is inactivation of Rho family of small GTPases (Durkin et al. 2007; Guan et al. 2008) by catalyzing the conversion of active GTP-bound, into GDP-bound inactive form, and thus blocking Rho pathway. The product of DLC1 gene was shown to inactivate RhoA, RhoB, RhoC and to some degree Cdc42, but not Rac (Zimonjic and Popescu 2012). DLC1 is frequently down regulated in prostate cancer by either epigenetic modifications or deletion (Guan et al. 2006) and its genomic under-representation at chromosome $8 \mathrm{p}$ is associated with aggressive form of prostate cancer (Matsuyama et al. 2001). Both C4-2-B2 and PC-3 cells are cancer cells and, as compared to 


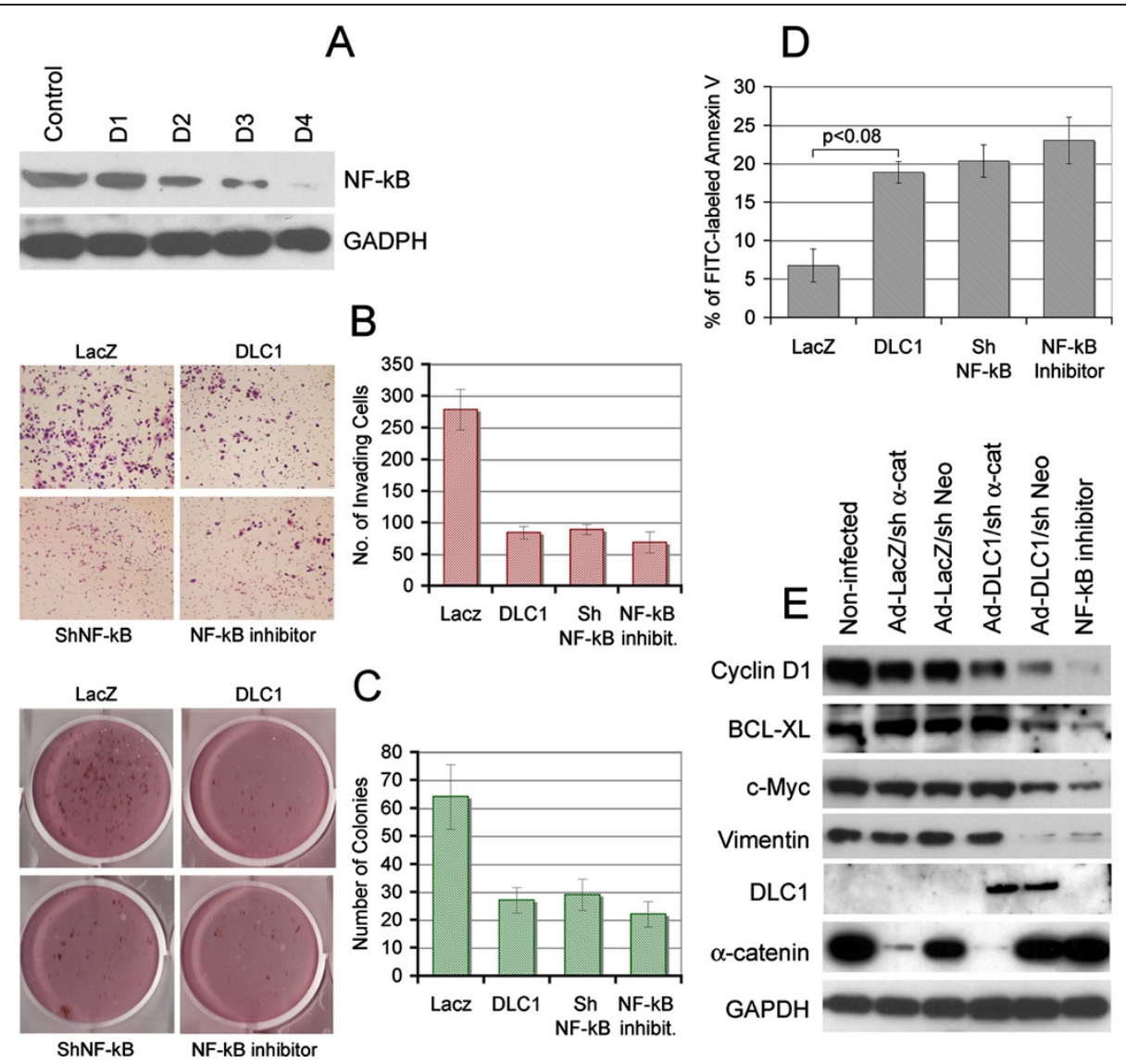

Figure 6 DLC1-mediated NF-KB suppression shows effects similar to sh(p65)NF-kB silencing or pharmacological down regulation of NF-KB. (A) Western blot showing NF-KB (p65) knock down, D1, D2, D3 and D4 are different clones. Clone D4 was taken for study. Microphotographs and/or quantitative valuation of Invasion Assay (B) Colony Formation (C) and Apoptosis Assay (D) of C4-2-B2 cells transduced with Lac Z or DLC1, stably transfected with shNF-kB or treated with NF-kB inhibitor (Peptide inhibitor $150 \mu \mathrm{M}$ ). (E) Western blot analysis of NF-kB-induced genes in cell extract from C4-2-B2 transduced and stably transfected with Ad-LacZ + sh-a-catenin, Ad-LacZ + sh-Neo, Ad-DLC1 + sh-a-catenin, Ad-DLC1 + sh-Neo, or NF-KB peptide inhibitor $(150 \mu \mathrm{M})$.

normal cells such as RWPE-1, exhibit higher level of RhoA. High level of total RhoA could affect Rho activity only if RhoGAPs such as DLC1 - for which these cells are negative - are absent. Otherwise, high total RhoA would not have much effect on overall Rho activity. Therefore, DLC1-mediated suppression of NF-kB activation could be a reflection of disruption of Rho signaling pathway by one powerful RhoGAP, even more so given that the results presented above demonstrated the dependence of suppression on DLC1's GAP activity. Yet, the fact that re-expression of DLC1 alone was not sufficient to affect NF-kB activation in $\alpha$-catenin-negative PC3 cells, as opposed to $\alpha$-catenin positive C4-2-B2 cells, points to a more complex mechanism.

Loss of $\alpha$-catenin in cancer cells results in increased cell proliferation and resistance to apoptosis (Liu et al. 2007; Lien et al. 2006) whereas variations in availability of either $\alpha$-catenin or $\beta$-catenin were shown to influence functional status of NF-kB (Deng et al., 2002; Kobielak and Fuchs 2006; Solanas et al. 2008). Increased activation of NF-kB in C4-2-B2 and PC3 cells occurred in absence of either DLC1 or $\alpha$-catenin - or both of them - whereas only the simultaneous expression of DLC1 and $\alpha$-catenin was effective in suppressing the NF- $k B$ activity, thus portraying DLC1's GAP function as necessary, but not enough. However, just removal of calcium from chemical environment was sufficient to cancel the joint DLC1- $\alpha$-catenin suppression of NF- $\mathrm{kB}$ activation.

Calcium is instrumental for formation and integrity of contact points between epithelial cells - adherens junctions (AJ) - whose major molecular component is Ecadherin, which maintains the connection to the actin cytoskeleton through interaction with catenins (Wheelock and Johnson 2003), and whose loss leads to up-regulation of NF- $\kappa B$ activity (Kuphal et al. 2004). Conversely, stable association of NF- $\mathrm{kB}$ with AJ's proteins, primarily Ecadherin, reduces its activity (Solanas et al. 2008; Kuphal et al. 2004). Apparently, such immobilization of NF- $\mathrm{kB}$ is enabled by $\beta$ catenin, which acts as possible link between p65 subunit of NF- $\mathrm{kB}$ and adherens junctions (Solanas 
et al. 2008; Kuphal et al. 2004). DLC1 contributes to AJ's stabilization through its interaction with E-cadherin via $\alpha$ catenin or by inducing E-cadherin expression (Tripathi et al. 2012; Tripathi et al. 2013). One of the consequences of increased AJ's stability is down-regulation of RhoGTPases (Asnaghi et al. 2010). As our aforementioned analysis of membrane and cytosolic cellular fractions showed, DLC1 expression resulted in higher rate of association of p65 subunit with the membrane, thus signaling increased membrane localization of NF- $\mathrm{kB}$, which coincided with its reduced activity.

Inhibition of NF- $\mathrm{kB}$ activity in human prostate cancer cells suppresses invasion, metastasis, and neoangiogenesis (Huang et al. 2001). Our results show that a major NF- $\kappa B$ inhibitor, IкB $\alpha$, whose IKK-mediated phosphorylation, ubiquitination and subsequent degradation takes place in membrane ruffles (Boyer et al. 2004) is indeed, localized in membrane ruffles of DLC-1 negative cells but is relocated into cytoplasm and, thus, rescued from proteasomal degradation in cells with restored DLC1 expression. Although I $\mathrm{B} \alpha \alpha$ physically interacts with cytoskeleton-associated protein (Crepieux et al. 1997), we do not have any evidence that DLC1 and I $\kappa \mathrm{B} \alpha$ proteins directly interacts with each other. The fact that such a process is contingent on presence of calcium, reaffirms that the stability of AJs, resulting from intricate molecular interactions between DLC1, $\alpha$-catenin and E-cadherin, appears to play a major role in regulating NF- $\mathrm{kB}$ activity.

\section{Conclusions}

This study provides new evidences that tumor suppressor gene DLC1, through its RhoGAP activity, affects the activation of NF-kB and, thus, modulates the complex signal transduction pathways, which associate with inflammatory response and cancer progression. It expands the known DLC1 role and opens the prospect that DLC1 introduction, or the inhibition of downstream pathways activated by DLC1 deficiency, could sensitize chemotherapy-resistant metastatic cancer to various pharmacological drugs.

\section{Methods}

\section{Cell lines and culture conditions}

C4-2-B2 cell line was purchased from ViroMed, lab Inc (Minneapolis, MN) and cultured in T-medium (Invitrogen, San Diego, CA) containing 10\% FBS. PC-3 and RWPE-1 cells lines were purchased from American Type Culture Collection (Rockville, MD). PC-3 was cultured in RPMI 1640 medium (Invitrogen, San Diego, CA) and RWPE-1 was cultured in keratinocyte medium (Invitrogen, San Diego, CA) supplemented with Epithelial Growth Factor (Invitrogen, San Diego, CA) and Bovine Pituitary Extract (Invitrogen, San Diego, CA). All cell cultures were grown in a humidified $\mathrm{CO}_{2}$ incubator at $37^{\circ} \mathrm{C}$.

\section{Plasmids and transfections}

For stable knock down of NF-kB (P65 subunit), four respective SureSilencing shRNA plasmid vectors (KH01812P, SA Biosciences, Frederick, MD), containing puromycinresistance gene were transfected using lipofectamine 2000 (Invitrogen, San Diego, CA). The media containing puromycin was changed after 48 hours. For stable transfection of $\alpha$-catenin (KH00646N with neomycin) short hairpin RNA (shRNA) and for DLC1 knock down (KH00438P with Puromycin), SureSilencing shRNA plasmid vectors (SA Biosciences, Frederick, MD) were transfected using Lipofectamine 2000, and medium containing appropriate antibiotics was changed after $48 \mathrm{~h}$. Two weeks after transfection, single colonies were picked up and expanded. Stable clone for DLC1 R718E was made using G418 resistance. An adenovirus encoding either DLC1 cDNA or LacZ was prepared and transduced as previously described (Guan et al., 2008). Adenovirus encoding $\alpha$-catenin was purchased from Vector Biolabs (Philadelphia, PA).

\section{Immunoprecipitation and western blotting}

Cells were transduced or transfected with various DLC1 constructs, $\alpha$-catenin, and/or GFP-cadherin and lysed with NP-40 lysis buffer (BioSource, Camarillo, CA) containing Protease Inhibitor Cocktail (Sigma, St Lois, MO). Centrifugation was done for $20 \mathrm{~min}$ at $12,000 \times \mathrm{g}$ to produce lysate for western blot or immunoprecipitation. Anti-GFP antibody was added into precleared cell lysates and incubated overnight at $4^{\circ} \mathrm{C}$. Protein G-Sepharose slurry (Zymed Inc., San Francisco, CA, USA) was added and incubated for additional 2-3 hours. Immunoprecipitates were washed and loaded on 4-12\% SDS-PAGE gels (Invitrogen, Carlsbad, CA), transferred to nitrocellulose membranes (Invitrogen, Carlsbad, CA) and western blotted with anti NF- $\mathrm{kB}$ antibody. Proteins were visualized by horseradish peroxidase-conjugated secondary antibodies and chemiluminescent HRP substrate (Millipore, Billerica, MA). The following antibodies were used for western blot: DLC1 monoclonal antibody (BD Transduction Laboratories, San Diego, CA), Anti-V5 (Invitrogen, Carlsbad, CA), $\alpha$-catenin and IкB $\alpha$ (Santa Cruz Biotechnology, Santa Cruz, CA), NF-кB (p65) and Phospho p65 antibody (Cell-signaling, Danvers, MA), and pIkB $\alpha$ and GFP antibodies (Abcam, Cambridge, MA).

\section{Immunofluorescence analysis}

Cells were fixed in $4.0 \%$ paraformaldehyde for $20 \mathrm{~min}$, permeabilized with $0.2 \%$ Triton- X for $5 \mathrm{~min}$, and then subjected to staining with following antibodies: Goat polyclonal DLC1, mouse monoclonal anti-E-cadherin, anti$\alpha$-catenin, anti-NF-kB (p65) (Santa Cruz Biotechnology, Santa Cruz, CA), and pNF-kB (Cell-signaling Danvers, MA). For detection, anti-mouse Alexa Fluor 488, anti-goat Alexa Fluor568, and anti-mouse Alexa Fluor 650 
(Molecular probe, Carlsbad, CA) were used. Stained cells were examined by a Zeiss LSM 510 NLO confocal system (Carl Zeiss Inc, Thornwood, NY, USA) with an inverted microscope (Axiovert $200 \mathrm{M}$ ) and a $30 \mathrm{~mW}$ argon laser tuned to $488 \mathrm{~nm}$, a $1 \mathrm{~mW}$ HeNe laser tuned to $543 \mathrm{~nm}$ and a $1 \mathrm{~mW}$ HeNe laser tuned to $633 \mathrm{~nm}$. Images were collected using a $63 \times$ Plan-Apochromat $1.4 \mathrm{NA}$ oil immersion objective and a multi-track configuration in Zeiss AIM software (v. 4.0) where the Alexa 488, Alexa 594, and Alexa 633 signals were sequentially collected in separate PMTs with a BP 500-530 nm filter, BP 565-615 nm filter and BP 650-710 filter. Zoom was set at 0.8 and images were $512 \times 512$ pixels with line averaging of 4 .

\section{Preparation of sub cellular fractions}

Subcellular fractions were prepared as described previously (Hodge et al. 2003). Briefly, cells were washed in ice-cold PBS twice, to remove all media, then washed in buffer A (100 mM sucrose, 20 mM HEPES pH 7.4, $1.5 \mathrm{Mm} \mathrm{MgCl} 2$, $1 \mathrm{mM}$ EGTA, $1 \mathrm{mM}$ EDTA and $1 \mathrm{mM}$ DTT) and resuspended in $500 \mu \mathrm{l}$ of buffer B [buffer A plus 5\% Percoll, $0.01 \%$ digitonin, protease inhibitors cocktails and $1 \mathrm{mM}$ phenylmethylsulfonyl fluoride. After 20 min incubation on ice, the supernatant was centrifuged for $15 \mathrm{~min}$ at $15,000 \times \mathrm{g}$ to pellet mitochondria. Then supernatant was centrifuged further at $100,000 \times \mathrm{g}$ for $1 \mathrm{~h}$. After centrifugation, supernatant and pellet were designated as the cytosolic and membrane fractions, respectively. Membrane pallet was washed twice with Buffer A and then dissolved in appropriate amount of Buffer A supplemented with 1.0\% Triton-X.

\section{RhoA activation assay}

RhoA activation assay was done according to manufacturer's (Cell Biolabs, San Diego, CA) instructions. Briefly, cells were lysed in $1 \mathrm{X}$ lysis buffer supplemented with protease inhibitors cocktail (Sigma-Aldrich, St. Louis, $\mathrm{MO}$ ) and the lysate was centrifuged at $4^{\circ} \mathrm{C}$ for $10 \mathrm{~min}$ at $12,000 \times \mathrm{g}$. An aliquot of lysate was analyzed for total protein content and total RhoA, and the rest of the lysates was used for the Rhotekin assay. Rhotekin beads were added to cell lysates, incubated for 4 hours, and washed thoroughly 3-4 times in washing buffer. Active Rho protein bound to beads was separated in $4-12 \%$ acrylamide gels and immunoblotted with anti-RhoA antibody (Abcam, Cambridge, MA).

\section{Ubiquitination assay}

C42-B2 cells were transduced with Ad-LacZ/Ad-DLC1 or transfected with R718E DLC1. Cells were treated for 8 hours with $10 \mu \mathrm{M}$ of proteasome inhibitor MG132
(Sigma-Aldrich, St. Louis, MO), lysed and the lysates were precleared. Ten micrograms of IкB $\alpha$ antibody were added to $500 \mu \mathrm{g}$ of cell lysate and incubated in cold room for 4 hours. Then, protein $G$ sepharose was added and incubated for further 2 hours. After centrifugation at $5000 \mathrm{~g}$ for $5 \mathrm{~min}$, pellets were washed 3-4 times with lysis buffer, proteins were boiled in loading buffer and subjected to immunoblotting analyses with anti-ubiquitin antibody.

\section{Colony formation in soft agar}

Soft agar assay was performed using Cell Transformation Detection Assay kit (Chemicon, Temecula, CA). Cells were suspended in $0.35 \%$ low melting agarose at $2 \times 10^{4}$ cells per well, plated on a layer of $0.8 \%$ agarose/ T-medium (5\%) in six-well culture plates and cultured at $37^{\circ} \mathrm{C}$ with $5 \% \mathrm{CO}_{2}$. After 4 weeks, colonies were stained and imaged.

\section{Apoptosis analysis}

Cells were harvested by trypsinization and washed twice with ice-cold PBS. Samples were centrifuged for $3 \mathrm{~min}$ at $200 \times \mathrm{g}$, rinsed with PBS, and re-suspended in FITClabeled annexinV/propidium iodide (PI) according to the manufacturers instructions (Chemicon, Temecula, CA). Apoptotic cells were analyzed by flow cytometry on a FACScan Instrument (Becton Dickinson, San Jose, CA).

\section{Invasion assay}

Cell invasion assays were performed using $8 \mu \mathrm{m}$ poresize chambers (Becton Dickinson, Franklin Lakes, NJ). Cells were transduced with Ad-DLC1 or Ad-LacZ or stably transfected with ShRNA of NF-kB or treated with $150 \mu \mathrm{M}$ of peptide inhibitor of NF- $\kappa B$ (IMGENEX, San Diego, CA) and $1 \times 10^{6}$ cells/well were plated on ECMatrix coated cell culture inserts. After incubation, the non-invading cells were removed from the interior of the inserts using a cotton-tipped swab. Invaded cells were stained with DiffQuick and counted (Dade Behring, Newark, DE, USA).

\section{Luciferase reporter assay}

Ad-LacZ or DLC1 transduced C4-2-B2, and $\alpha$-catenin transduced PC-3 cells were transfected with $\mathrm{NF}_{\kappa} \mathrm{B}$ reporter plasmid, or negative and positive control plasmid (SA Biosciences, Frederick, $\mathrm{MD}$ ) and incubated for 48 hours. Cells were washed with PBS (pH-7.6) and lysed with reporter lysis buffer (Promega, Madison, WI). After centrifugation for 10 mins, supernatant was collected. Luciferase activity was measured using the Dual-Luciferase Reporter Assay System (Promega, Madison, WI). 


\section{Statistical analysis}

Statistical analysis of quantitative data was carried out when appropriate, and levels of statistical significance were assessed using two-tailed paired Student's T- test. All numerical values represent means \pm S.E.M from three independent experiments.

\section{Ethical approval}

This research study has been conducted in full compliance with the "Guidelines for the Conduct of Research in the Intramural Research Program at NIH", issued by the NIH Committee on Scientific Conduct and Ethics, and approved by the NIH Scientific Directors (4th Edition, May 2007).

\section{Competing interests}

The authors declare that they have no competing interests.

\section{Authors' contributions}

$\mathrm{VT}$ and DBZ developed the concept of the study. VT carried out the experiments and produced the drafts of the manuscript and figures. NCP participated in the design of experiments and helped with drafting the manuscript. DBZ wrote the final version of the manuscript and prepared the final version of the figures. All authors read and approved the final manuscript.

\section{Acknowledgement}

This research was supported by the Intramural Research Program of the National Cancer Institute, National Institutes of Health, Bethesda, Maryland, USA.

Received: 29 August 2013 Accepted: 9 January 2014

Published: 14 January 2014

\section{References}

Albany C, Alva AS, Aparicio AM, Singal R, Yellapragada S, Sonpavde G, Hahn NM (2011) Epigenetics in prostate cancer. Prostate Cancer, doi:10.1155/2011/580318

Amit S, Ben-Neriah Y (2003) NF-kappaB activation in cancer: a challenge for ubiquitination- and proteasome-based therapeutic approach. Semin Cancer Biol 13:15-28

Andela VB, Gordon AH, Zotalis G, Rosier RN, Goater JJ, Lewis GD, Schwarz EM, Puzas JE, O'Keefe RJ (2003) NFkappaB: a pivotal transcription factor in prostate cancer metastasis to bone. Clin Orthop Relat Res 415S:75-85

Asnaghi L, Vass WC, Quadri R, Day PM, Qian X, Braverman R, Papageorge AG, Lowy DR (2010) E-cadherin negatively regulates neoplastic growth in non-small cell lung cancer: role of Rho GTPases. Oncogene 29:2760-2771

Biswas DK, Shi Q, Baily S, Strickland I, Ghosh S, Pardee AB, Iglehart JD (2004) NF-kappa B activation in human breast cancer specimens and its role in cell proliferation and apoptosis. Proc Natl Acad Sci U S A 101:10137-10142

Boyer L, Travaglione S, Falzano L, Gauthier NC, Popoff MR, Lemichez E, Fiorentini C, Fabbri A (2004) Rac GTPase instructs nuclear factor-kappaB activation by conveying the SCF complex and IkBalpha to the ruffling membranes. Mol Biol Cell 15:1124-1133

Cammarano MS, Minden A (2001) Dbl and the Rho GTPases activate NF kappa B by I kappa B kinase (IKK)-dependent and IKK-independent pathways. J Biol Chem 276:25876-25882

Catz SD, Johnson JL (2001) Transcriptional regulation of bcl-2 by nuclear factor kappa B and its significance in prostate cancer. Oncogene 20:7342-7351

Chiao PJ, Na R, Niu J, Sclabas GM, Dong Q, Curley SA (2002) Role of Rel/NF-kappaB transcription factors in apoptosis of human hepatocellular carcinoma cells. Cancer 95:1696-1705

Crépieux P, Kwon H, Leclerc N, Spencer W, Richard S, Lin R, Hiscott J (1997) I kappaB alpha physically interacts with a cytoskeleton-associated protein through its signal response domain. Mol Cell Biol 17:7375-7385

Deng J, Miller SA, Wang HY, Xia W, Wen Y, Zhou BP, Li Y, Lin SY, Hung MC (2002) beta-catenin interacts with and inhibits NF-kappa B in human colon and breast cancer. Cancer Cell 2(4):323-334
Durkin ME, Yuan BZ, Zhou X, Zimonjic DB, Lowy DR, Thorgeirsson SS, Popescu NC (2007) DLC-1:a Rho GTPase-activating protein and tumour suppressor. J Cell Mol Med 11:1185-1207

Gasparian AV, Yao YJ, Kowalczyk D, Lyakh LA, Karseladze A, Slaga TJ, Budunova IV (2002) The role of IKK in constitutive activation of NF-kappaB transcription factor in prostate carcinoma cells. J Cell Sci 115:141-151

Ghosh S, Karin M (2002) Missing pieces in the NF-kappaB puzzle. Cell 109(Suppl):S81-S96

Gnad R, Kaina B, Fritz G (2001) Rho GTPases are involved in the regulation of NF-kappaB by genotoxic stress. Exp Cell Res 264:244-249

Guan M, Zhou X, Soulitzis N, Spandidos DA, Popescu NC (2006) Aberrant methylation and deacetylation of deleted in liver cancer-1 gene in prostate cancer: potential clinical applications. Clin Cancer Res 12:1412-1419

Guan M, Tripathi V, Zhou X, Popescu NC (2008) Adenovirus-mediated restoration of expression of the tumor suppressor gene DLC1 inhibits the proliferation and tumorigenicity of aggressive, androgen-independent human prostate cancer cell lines: prospects for gene therapy. Cancer Gene Ther 15:371-381

Hafeez BB, Siddiqui IA, Asim M, Malik A, Afaq F, Adhami VM, Saleem M, Din M, Mukhtar H (2008) A dietary anthocyanidin delphinidin induces apoptosis of human prostate cancer PC3 cells in vitro and in vivo: involvement of nuclear factor-kappaB signaling. Cancer Res 68:8564-8572

Hodge JC, Bub J, Kaul S, Kajdacsy-Balla A, Lindholm PF (2003) Requirement of RhoA activity for increased nuclear factor kappaB activity and PC-3 human prostate cancer cell invasion. Cancer Res 63:1359-1364

Hoffmann A, Leung TH, Baltimore D (2003) Genetic analysis of NFkappaB/ Rel transcription factors defines functional specificities. EMBO J 22:5530-5539

Hsieh CL, Oakley-Girvan I, Balise RR, Halpern J, Gallagher RP, Wu AH, Kolonel LN, O'Brien LE, Lin IG, Van Den Berg DJ, Teh CZ, West DW, Whittemore AS (2001) A genome screen of families with multiple cases of prostate cancer: evidence of genetic heterogeneity. Am J Hum Genet 69:148-158

Huang S, Pettaway CA, Uehara H, Bucana CD, Fidler IJ (2001) Blockade of NF-kappaB activity in human prostate cancer cells is associated with suppression of angiogenesis, invasion, and metastasis. Oncogene 20:4188-4197

Huber MA, Azoitei N, Baumann B, Grünert S, Sommer A, Pehamberger H, Kraut N, Beug H, Wirth T (2004) NF-kappaB is essential for epithelial-mesenchymal transition and metastasis in a model of breast cancer progression. J Clin Invest 114:569-581

Julien S, Puig I, Caretti E, Bonaventure J, Nelles L, van Roy F, Dargemont C, de Herreros AG, Bellacosa A, Larue L (2007) Activation of NF-kappaB by Akt upregulates Snail expression and induces epithelium mesenchyme transition. Oncogene 26:7445-7456

Karin M, Cao Y, Greten FR, Li ZW (2002) NF-kappaB in cancer: from innocent bystander to major culprit. Nat Rev Cancer 2:301-310

Kobielak A, Fuchs E (2006) Links between alpha-catenin, NF-kappaB, and squamous cell carcinoma in skin. Proc Natl Acad Sci U S A 103:2322-2327

Kuphal S, Poser I, Jobin C, Hellerbrand C, Bosserhoff AK (2004) Loss of E-cadherin leads to upregulation of NFkappaB activity in malignant melanoma. Oncogene 23:8509-8519

Lien WH, Klezovitch O, Fernandez TE, Delrow J, Vasioukhin V (2006) alphaE-catenin controls cerebral cortical size by regulating the hedgehog signaling pathway. Science 311:1609-1612

Liu TX, Becker MW, Jelinek J, Wu WS, Deng M, Mikhalkevich N, Hsu K, Bloomfield CD, Stone RM, DeAngelo DJ, Galinsky IA, Issa JP, Clarke MF, Look AT (2007) Chromosome $5 \mathrm{q}$ deletion and epigenetic suppression of the gene encoding alpha-catenin (CTNNA1) in myeloid cell transformation. Nat Med 13:78-83

Luo JL, Kamata H, Karin M (2005) IKK/NF-kappaB signaling: balancing life and death-a new approach to cancer therapy. J Clin Invest 115:2625-2632

Matsuyama H, Pan Y, Oba K, Yoshihiro S, Matsuda K, Hägarth L, Kudren D, Naito K, Bergerheim USR, Ekman P (2001) Deletions on chromosome 8p22 may predict disease progression as well as pathological staging in prostate cancer. Clin Cancer Res 7:3139-3143

Pajonk F, Pajonk K, McBride WH (1999) Inhibition of NF-kappaB, clonogenicity, and radiosensitivity of human cancer cells. J Natl Cancer Inst 91:1956-1960

Palayoor ST, Youmell MY, Calderwood SK, Coleman CN, Price BD (1999) Constitutive activation of IkappaB kinase alpha and NF-kappaB in prostate cancer cells is inhibited by ibuprofen. Oncogene 18:7389-7394

Park BK, Zhang H, Zeng Q, Dai J, Keller ET, Giordano T, Gu K, Shah V, Pei L, Zarbo RJ, McCauley L, Shi S, Chen S, Wang CY (2007) NF-kappaB in breast cancer cells promotes osteolytic bone metastasis by inducing osteoclastogenesis via GM-CSF. Nat Med 13:62-69 

Genes Dev 11:463-475

Pickering BM, de Mel S, Lee M, Howell M, Habens F, Dallman CL, Neville LA, Potter KN, Mann J, Mann DA, Johnson PW, Stevenson FK, Packham G (2007) Pharmacological inhibitors of NF-kappaB accelerate apoptosis in chronic lymphocytic leukaemia cells. Oncogene 26:1166-1177

Pikarsky E, Porat RM, Stein I, Abramovitch R, Amit S, Kasem S, Gutkovich-Pyest E, Urieli-Shoval S, Galun E, Ben-Neriah Y (2004) NF-kappaB functions as a tumour promoter in inflammation-associated cancer. Nature 431:461-466

Segain JP, Raingeard de la Blétière D, Sauzeau V, Bourreille A, Hilaret G, Cario-Toumaniantz C, Pacaud P, Galmiche JP, Loirand G (2003) Rho kinase blockade prevents inflammation via nuclear factor kappa B inhibition: evidence in Crohn's disease and experimental colitis. Gastroenterology 124:1180-1187

Shih YP, Liao YC, Lin Y, Lo SH (2010) DLC1 negatively regulates angiogenesis in a paracrine fashion. Cancer Res 70:8270-8275

Solanas G, Porta-de-la-Riva M, Agustí C, Casagolda D, Sánchez-Aguilera F, Larriba MJ, Pons F, Peiró S, Escrivà M, Muñoz A, Duñach M, de Herreros AG, Baulida J (2008) E-cadherin controls beta-catenin and NF-kappaB transcriptional activity in mesenchymal gene expression. J Cell Sci 121:2224-2234

Suh J, Payvandi F, Edelstein LC, Amenta PS, Zong WX, Gélinas C, Rabson AB (2002) Mechanisms of constitutive NF-kappaB activation in human prostate cancer cells. Prostate 52:183-200

Sweeney C, Li L, Shanmugam R, Bhat-Nakshatri P, Jayaprakasan V, Baldridge LA, Gardner T, Smith M, Nakshatri H, Cheng L (2004) Nuclear factor-kappaB is constitutively activated in prostate cancer in vitro and is overexpressed in prostatic intraepithelial neoplasia and adenocarcinoma of the prostate. Clin Cancer Res 10:5501-5507

Tapia MA, González-Navarrete I, Dalmases A, Bosch M, Rodriguez-Fanjul V, Rolfe M, Ross JS, Mezquita J, Mezquita C, Bachs O, Gascón P, Rojo F, Perona R, Rovira A, Albanell J (2007) Inhibition of the canonical IKK/NF kappa B pathway sensitizes human cancer cells to doxorubicin. Cell Cycle 6:2284-2292

Tripathi V, Popescu NC, Zimonjic DB (2012) DLC1 interaction with a-catenin stabilizes adherens junctions and enhances DLC1 antioncogenic activity. Mol Cell Biol 32:2145-2159

Tripathi V, Popescu NC, Zimonjic DB (2013) DLC1 induces expression of E-cadherin in prostate cancer cells through Rho pathway and suppresses invasion. Oncogene, doi: 10.1038/onc.2013.7

Ullmannova-Benson V, Guan M, Zhou X, Tripathi V, Yang XY, Zimonjic DB, Popescu NC (2009) DLC1 tumor suppressor gene inhibits migration and invasion of multiple myeloma cells through RhoA GTPase pathway. Leukemia 23:383-390

Wheelock MJ, Johnson KR (2003) Cadherins as modulators of cellular phenotype. Annu Rev Cell Dev Biol 19:207-235

Wilson KF, Erickson JW, Antonyak MA, Cerione RA (2013) Rho GTPases and their roles in cancer metabolism. Trends Mol Med 19:74-82

Xu J, Zheng SL, Komiya A, Mychaleckyj JC, Isaacs SD, Hu JJ, Sterling D, Lange EM, Hawkins GA, Turner A, Ewing CM, Faith DA, Johnson JR, Suzuki H, Bujnovszky P, Wiley KE, DeMarzo AM, Bova GS, Chang B, Hall MC, McCullough DL, Partin AW, Kassabian VS, Carpten JD, Bailey-Wilson JE, Trent JM, Ohar J, Bleecker ER, Walsh PC, Isaacs WB, Meyers DA (2002) Germline mutations and sequence variants of the macrophage scavenger receptor 1 gene are associated with prostate cancer risk. Nat Genet 32:321-325

Zimonjic DB, Popecu NC (2012) Role of DLC1 tumor suppressor gene and Myc oncogene in pathogenesis of hujman hepatocellular carcinoma: potential prospects for combined targeted therapeutics. Int J Oncology 41:393-406

doi:10.1186/2193-1801-3-27

Cite this article as: Tripathi et al:: DLC1 suppresses NF-KB activity in prostate cancer cells due to its stabilizing effect on adherens junctions. SpringerPlus 2014 3:27.

\section{Submit your manuscript to a SpringerOpen ${ }^{\odot}$ journal and benefit from:}

- Convenient online submission

- Rigorous peer review

- Immediate publication on acceptance

- Open access: articles freely available online

- High visibility within the field

- Retaining the copyright to your article

Submit your next manuscript at $\gg$ springeropen.com 